International Journal of Instruction e-ISSN: 1308-1470 • www.e-iji.net

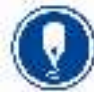

April 2021 • Vol.14, No.2

p-ISSN: 1694-609X

pp. $179-196$

Article submission code

20190802145112

Received: 02/08/2019

Revision: 03/09/2020
Accepted: $27 / 09 / 2020$

OnlineFirst: 16/01/2021

\title{
Character Thematic Education Game “AK@R" of Society Themes for Children with Malang-Indonesian Visualize
}

\author{
Andy Pramono \\ Lecturer, Universitas Negeri Malang, Malang, Indonesia, andy.pramono.fs@um.ac.id
}

Pujiyanto

Lecturer, Universitas Negeri Malang, Malang, Indonesia, pujiyanto.fs@um.ac.id

\section{Betty Dewi Puspasari}

Lecturer, STT Atlas Nusantara Malang, Malang, Indonesia, prasari1611@yahoo.com

\section{Nadhifa Salmatia Dhanti}

Universitas Negeri Malang, Malang, Indonesia,nadhh20@gmail.com

The game application is one of the leading choices of cellular media users, according to a report from the Ministry of Communication and Information of Indonesia, at least 30 million are children and adults. However, there is a sharp perception that interactive games hinder children's education, which impacts lazy children to learn. This article aims to convey the implementation of thematic games for children's education. Social improvement activities emphasize the thematic patterns of this educational game. The game developed is asynchronous, which means that the teacher must see students evaluate learning outcomes. This study uses the R\&D method through the procedures carried out as well as through pre and post-tests in the control class and experimental class. Data observation methods consisted of visual concepts, cultural patterns as game content ideas, research related to character education, and fundamental knowledge related to character education material. The results showed that the efficiency of the game showed that there was an increase in child socio-physical expertise and skills, as well as changes in learning models for children and assessment models by the teacher. The importance of this research is the development of educational media in improving the character quality of early childhood.

Keywords: games, education, media, local content, AK@R, society themes

\section{INTRODUCTION}

Schools sometimes find it difficult to educate their students to be persistent and tireless. Education does not only develop knowledge but also behavior, speech, and attitude to succeed and innovate summarized in character education. Creativity in the learning process is essential for the teacher. Creating a classroom atmosphere that is inspiring for

Citation: Pramono, A., Pujiyanto., Puspasari, B. D., \& Dhanti, N. S. (2021). Character Thematic Education Game "AK@R" of Society Themes for Children with Malang-Indonesian Visualize. International Journal of Instruction, 14(2), 179-196. https://doi.org/10.29333/iji.2021.14211a 
students, creative, and enthusiastic is the task and responsibility of the teacher. Learning time becomes a time awaited by students. Creativity will be challenging to develop in conventional educational models. I hope that the Indonesian education world can become more advanced, need innovation in education to make it happen.

Thematic learning brings together several subjects in one theme of discussion thematic education of students as a space to explore knowledge and create new perceptions. Thematic learning does not bore students because learning is very actual and directly related to the environment. Thematic learning runs two-way communication, from teacher to student and from student to teacher. Learning with a model that supports improve student's higher-order thinking skills is through contextual and meaningful learning. Meaningful for students is learning based on experience (Astutik, 2016). By conducting research that provides concepts and forms that are close to the reality of a child's life, to provide meaningful learning. According to Sasmito, thematic research developed with worksheets for students with integrative models. This research conducted by giving sheets to students for each discussion of thematic learning material. This study presents results in improving the quality of student work by providing media in the form of worksheets (Sasmito, 2015).

In thematic learning, the teacher became facilitator and motivator. However, the teacher also positions it as a learning person. Knowing the background of the target audience is very important before an instructor can consider using games in class (Bae 2002). Creative teachers can find actual sub-themes, creatively integrate subject matter into thematic learning. Teachers need to be creative in finding media in the environment, and creative in finding moral messages in education.

The development of the game is very rapid. Today, the game has used in many educational scenarios (Manuaba, 2017) (Papoutsi \& Drigas, 2016)(Syahidi, 2019). The game is adaptable and flexible, making the game can develop with various types of models - the game application as a medium for learning (Hays, 2005). Sets can apply to any scientific field. Just select the content and model of the matching game. Games are beneficial in learning in a fun way. The game can develop other skills through sequential, verbal, visual, and kinetic activities and others (Besgen, Nilgun, \& Sara, 2015). Games on mobile devices help in implementing the application of learning. Through the concept of mobile learning, education can carry out anytime and anywhere (Sabani, Manuaba, \& Adi, t.t.). The importance of designing a game as the media of knowledge was implemented character education patterns that have present in grade 1 and two elementary school Thematic books into sub-game content (Besgen, 2015; Rabin, 2010). This visualization aims to bring awareness and application of science to children (Shuqin, 2012). This research was conducted to see the development of student character with the development of thematic media. this game is a thematic concept to improve social attitudes, independence, and increase knowledge and with asset design, visualize the local ideas of the city of Malang. The design concept is a package in the local theory of Malang that consists of visual characters, backgrounds, and equipment.

Achieving these objectives needs to be established through the development method. The method aims to direct the creative process of producing the media. The 
development starts from data mining related to the concept of learning media, formulating concept contents from sub-games taken from thematic themes, sharing thematic concept contents into learning attitude concepts, formulating sub-game design concepts, formulating game visual design concepts and formulating the game analysis.

The importance of the development of product design for smartphone-based digital thematic character games and local culture are 1) The development of this thematic character game design considered necessary because it provides input to the organizers of elementary school education. Through smartphone-based digital media and local cultural nuances, hope to help foster children's attitudes from an early age about social views, positions of independence, and increased knowledge./ 2) Growing sense of recognition, belonging and love of local culture. The design is related to the location of the city of Malang, such as transportation, equipment, life patterns and traditional games sourced from the local culture of the town of Malang., 3) the treasure of children's learning media extracted from the culture of the archipelago through the development of local culture-minded digital game design concepts.

\section{Research Objectives of The Study}

The objectives of the study are as follows:

1. Is there a significant influence on insights on thematic material on the experimental group in the two research groups?

2. Are there significant differences between the control class and the experimental class related to thematic material?

3. Is there an influence of teacher learning models related to game media on thematic material?

\section{REVIEW OF LITERATURE}

The nature of an active and impatient child must be balance with two-way communication by a companion with a child. Interactive game media can help deliver learning material optimally (Chien-Hung Lai, Yu-Chang Lin, Bin-Shyan Jong, \& YenTeh Hsia, 2014). The application of interactive games in early childhood education also raises enthusiasm and enthusiasm for children and helps children learn and shape characters. Active, interactive games are media that have the right visualization for children so that information delivered on target. Although there is an educational media game, the role of the teacher cannot rule out in the learning process (Fozdar, 2015). The teacher must accompany, see, evaluate the results that have done during the learning process. The Asynchronous model was chosen to bridge the learning process, where students are still required to meet the teacher to see the learning outcomes they have been doing through educational games (El-Abd, 2017). The studies related to the use of play in education, namely articles Learning IS Child's Play: Game-Based Learning in Computer Science Education in Journal ACM Transactions on Computing Education (TOCE) (Hosseini, Hartt, \& Mostafapour, 2019). There are studies related to the use of the game in education namely articles Back to the Gaming Board: Understanding Games and Education through Board Game Reviews in Society for Information Technology \& 
Teacher Education International Conference, Mar 26, 2018, in Washington, D.C., United States (Willet, Sukanya, Boltz, Greenhalgh, \& Koehler, t.t.)/. The studies related to the use of the game in education namely articles (Papoutsi \& Drigas, 2016). There are studies related to the use of the game result: It indicates that the use of game have great impact on students' reading achievement and learning motivation (Sofiana \& Mubarok, 2020). There are studies related to the use of the game: the interactive multimedia games can have beneficial effects on the emotional intelligence of the learners (Nakpong \& Chanchalor, 2019).

Consideration of what characteristics needed for early childhood. Aspects of personality towards the state, especially those related to ideology, nationalism, law, and citizenship known as a national character (Kokkalia \& Drigas, 2016; Kristianti, Purnawati, \& Suyoto, 2018). Children also need to be introduced to universal values such as respect, honesty, kindness, diligence, integrity, attention, tolerance, cooperation, hard work, patience, responsibility, and trustworthiness(Kokkalia \& Drigas, 2015). Now early childhood education faces many values proposed by various parties to include in the beginning and elementary education curriculum (Bae, 2002)

\section{METHOD}

The development of this research design is Research and Development (R \& D). This research intended to produce a product in the form of the @ Kar application, which is an abbreviation concept of character ethics. According to Sugiyono, R \& D is a method for producing a product while testing the effectiveness of the products produced. The results obtained with R \& D research in the field of education in the form of learning aids in the way of software such as learning models (Sugiyono, 2018).

The procedure used by researchers in the development of the @Kar game uses the process of developing Borg and Gall (Borg \& Gall, 2003) which explains the development research stages as follows: 1) Research and Information, 2) Planning, 3) Develop preliminary from product, 4) Preliminary field testing, 5) Main product revision, 6) Main field testing, 7) Operational product revision, 8, Operational field testing 9) Final product revision, and 10) Dissemination and implementation.

The details of the stages in this study illustrated in the following chart: 


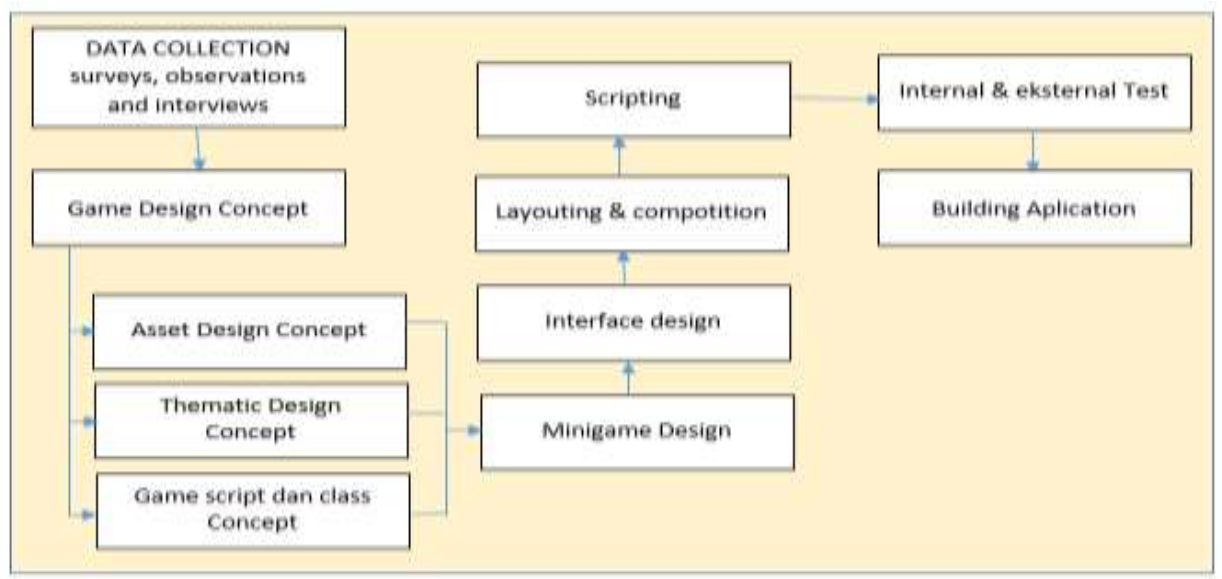

Figure 1

Research model

Then to be easily categorized, the stages grouped into three major groups as well as dividing them as follows: 1) preliminary study, 2) model development, and 3) model testing. Several steps, namely:

Stage I: Preliminary study, At this stage, information collection carried out with learning observations which have been carried out by elementary schools so far related to thematic material. Preliminary findings obtained that learning resources about thematic themes used in the form of printed books with content limited to thematic ethical studies. Shows that they have not yet covered thematic material in daily life, learning, and association (Nincarean. 2013). Therefore it is necessary to compile an application that contains thematic value material in everyday life, education, and association. Observations and studies of thematic design concepts of learning in several elementary schools. In this case, the primary school chosen in the city of Malang.

Stage II: @Kar game development. At this stage, the Android-based @Kar Game developed. The activities carried out are planning, including setting goals, determining content related to ethical values in daily life, in learning and association, determining the concept of asset design, building game design and testing the feasibility of the @ Kar game. The results of this activity are the Android-based @Kar game application that contains a study of ethical values in everyday life, in learning and association.

Stage III: Test the effectiveness of the Android-based @ Kar game application, At this stage, the effectiveness of the Android-based @Kar game application test carried out consisting of operational field testing and final product revision through experimental evaluation with pre-test and post-test - testing in elementary schools in Malang city, especially the Klojen sub-district. Field tests used for improvement guidelines. Then revise the product results in the form of methods or models according to the effects of field tests. The results can take into consideration in improving children's ethical values (Wallace \& Sheetz, 2014). 
The study conduct at one elementary-school district in Malang city, Indonesia. There were 2 schools. The number of teachers in each school varied from 6 teachers to each school. Most of the teachers in this school graduated from the Department of Basic Education. The number of students ranges from 30-35 students per class, depending on the size of the school. Due to the shortage of teachers in these schools, one teacher may be responsible for more than one subject. For example, some teachers teach two thematic issues.

This research conduct during the even semester, which consists of 16 weeks from September to December. About examinations, the midterm exams held in mid-October and the final exams take place in the last week of December. In addition to these two exams, the Education Test schedule for all class students.

In this study, the initial test conducted on participants in 6 classes with a total of 172 students. The participant divided into two experimental groups. Group 1 gets standard education without treatment, namely the learning model using module learning media and presentation media. Group 1 consisted of 86 students from classes A, B, and C. Group 2 gets education with standard media with additional treatment in the form of thematic games AK@R. Group 2 consisted of 86 students from classes D, E, and F. Then, the results were evaluated for groups 1 and 2 .

The evaluation results transcribed and coded. The analysis is carried out with two main steps, namely (1) examining in detail and carefully producing meaningful units of data and (2) classifying and grouping them in specific themes. Data encoded using open coding methods. Data obtained were analyzed by the researchers. To achieve the validity and reliability of the data collected, several actions were carried out by the researchers at the end of this study, namely: (1) the researcher informed the main results of the analysis conducted to the participants and asked them for opinions; (2) researchers ask for views from some experts in the same field, namely Learning Management Systems (LMS) and Thematic Education about how accurate the results obtained. This action aims to ensure that the data produced is correct and does not favor anyone.

Data obtained from the final evaluation were analyzed quantitatively using descriptive and inferential statistical methods - descriptive statistics present in the form of mean and standard deviation. Paired t-tests used to measure improving thematic learning skills in each group. ANCOVA was used to find differences between the experimental and control groups Data Collection

In the development of smartphone character-based game design with local visual culture, Malang city can divide into several events:

Data collection of this research which thematic themes from elementary school learning books. This stage of data mining refers to the grade 1 and grade 2 elementary school thematic learning books. This book is divided based on thematic topics, including the following table 
Based on the thematic theme shown in the table, the concepts of grouping thematic themes formulate into three groups, namely environment, association, and school. This grouping based on the suitability of the application of thematic patterns and criteria for achieving thematic themes base on the development of thematic theme groupings can see in the table below

Table 2

Grouping thematic

\begin{tabular}{ll}
\hline Class 1 Thematic & \\
\hline Myself & Environment \\
\hline My passion & Environment \\
\hline My activities & Society \\
\hline My experience & Environment \\
\hline Clean, healthy and beautiful environment & School \\
\hline Things, Animals, and Plants around me & Environment \\
\hline Natural events & School \\
\hline Class 2 Thematic & \\
\hline Live in harmony & School \\
\hline Play in my environment & Environment \\
\hline My daily duty & Environment \\
\hline Clean and healthy life & School \\
\hline My experience & Society \\
\hline Caring for Animals and Plants & Environment \\
\hline Togetherness & School \\
\hline
\end{tabular}

After the division of the game theme group, it will become a small game. Formulation The concept of game design is based on thematic themes. At this stage, it will be divided into two procedures, first determining mini-game titles based on thematic topics and second defining the concepts of mini-games.

The results of the search for data related to thematic topics in elementary thematic books can found in several theories about the thematic topic in each sub-chapter. After several searches related to the idea of the mini-game theme, the mini-game title is decided per thematic item, as shown in the table below. 
Table 3

Minigame concept

\begin{tabular}{ll}
\hline Thematic & Mini-Game Title \\
\hline Environment Scene & \\
\hline 1. myself & Arrange Card \\
\hline 2. My passion & Arrange Puzzle \\
\hline 3. My family & Clearinghouse \\
\hline 4. My daily duty & Feed animals \\
\hline 5. Objects, Animals, and Plants around me & Learn about animals \\
\hline Society Scene & \\
\hline 1. My activities & Buy goods \\
\hline 2. My experience & Playing kites \\
\hline 3. My experience & Play to help animals \\
\hline 4. Play in my environment & Play Jump Rope \\
\hline 5. Safety at home and travel & Clean up trash \\
\hline School Scene & \\
\hline 1. The environment is clean, healthy and beautiful & Maintain plants \\
\hline 2. Natural Events & Get to know animal sounds \\
\hline 3. Live in harmony & Playing numbers \\
\hline 4. Life is clean and healthy & Studying in laboratories \\
\hline 5. Togetherness & Class quiz \\
\hline
\end{tabular}

Use case Diagram is construction to describe the relationships that occur between actors with the activities contained in the application. Target use case modeling, among others, is to define the functional and operational needs of the system by setting the scene of the method used to build from the results of the analysis of existing applications.

After formulating a mini-game title based on existing thematic themes, then proceed with determining the concept of the minigame of each claim. This concept is related to game patterns, game targets, calculation of scores, and determination of background images and interface design. 


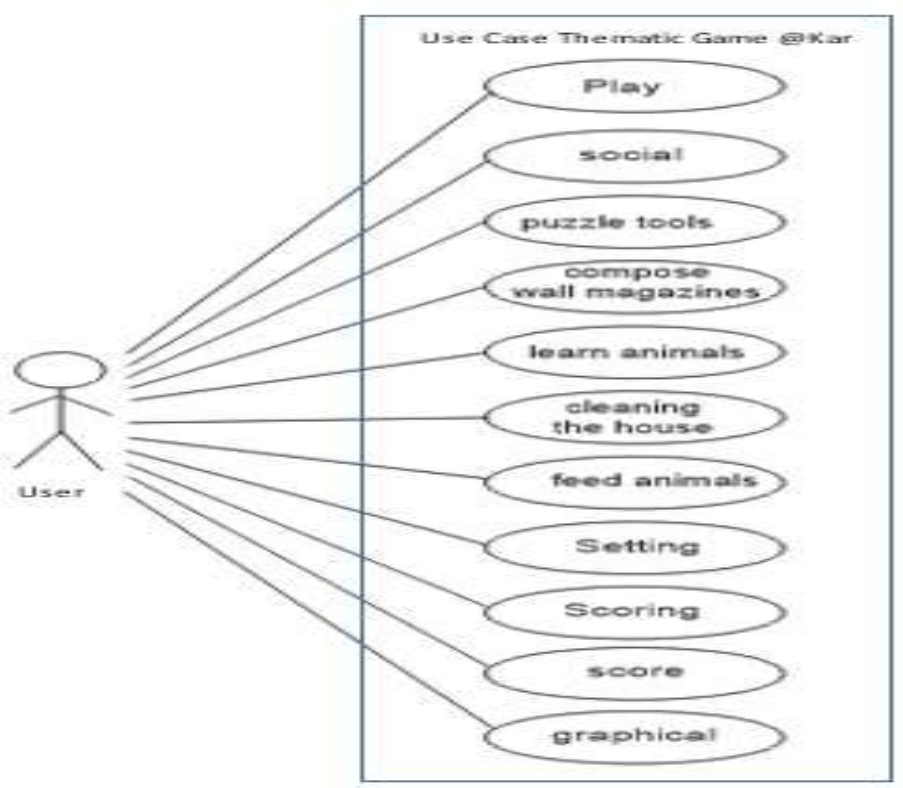

Figure 3

Use case diagram thematic game

We can convey three examples of the Minigame concept per scene from thematic games, as shown in the following presentation.

a. The concept of social theme minigame, taking the example of mini-games recognizing economics, emphasizes the character of independence and discipline. How to play match materials to be purchased according to the list. Players will get a score if the items purchased are by the file. This thematic will affect the assessment of social values.

Table 4

Social thematic concepts: learn economics

\begin{tabular}{lll}
\hline Thematic & Game Concept & Asset \\
\hline Learn Economic & Target Players learn to find targets chosen & Supermarket storefront background \\
& according to the examples given & Shopping item: 16 assets \\
& Roller and dialogue: 2 assets \\
\hline
\end{tabular}

b. The concept of a social mini-game theme: taking the example of kinetic minigames emphasizes rhythmic motor character and discipline are regulating the rhythm. How to play with tabs every time a bee comes. Players will get the value of birds to avoid bees. This thematic will affect the assessment of social benefits. 
Table 5

Social thematic concepts: helping animals

\begin{tabular}{lll}
\hline Thematic & Game Concept & Asset \\
\hline Helping Animals & Target players learn to help birds & $\begin{array}{l}\text { Background: bird's nest on the square } \\
\text { birds: 3 pictures } \\
\text { to avoid bees }\end{array}$ \\
& & bee: 3 assets \\
\hline
\end{tabular}

c. The concept of a social theme minigame: take the example of a mini-game playing kites giving motoric emphasis and discipline. How to play: set the rhythm, so the kite does not go down and avoid animals. The player will get the winning position value. This thematic will affect the assessment of social values

Interface arrangement compiled a flow diagram, which is the concept of interface flow from thematic games. This flow chart is the basis for determining the flow of the display from the main show to the mini-game

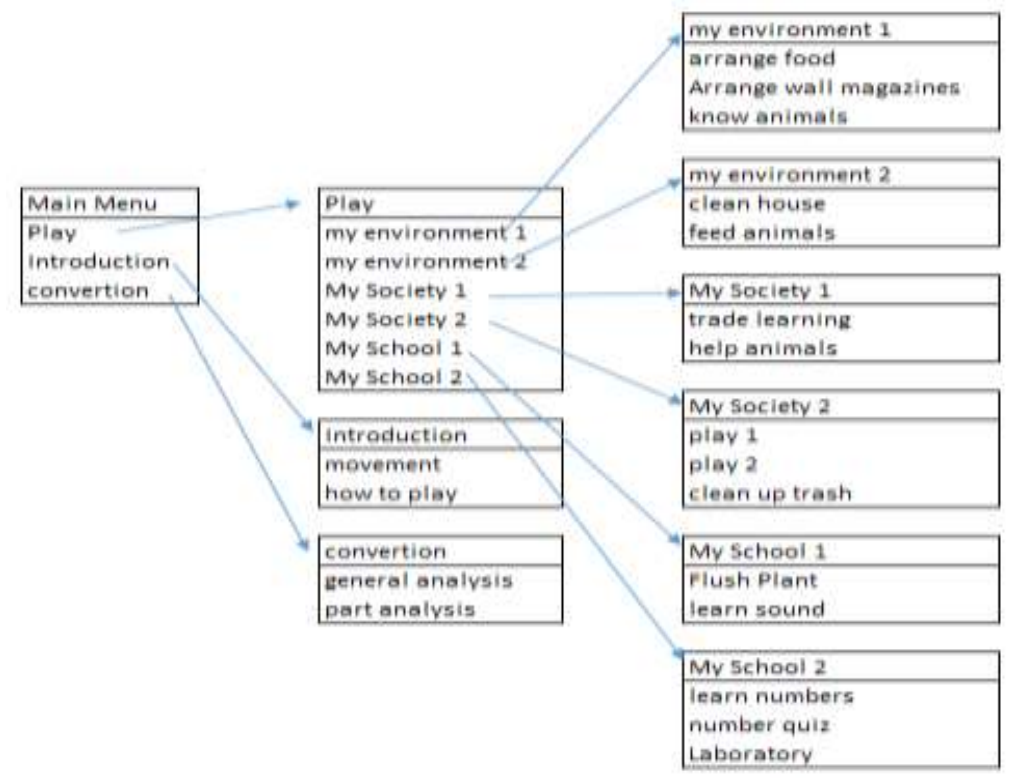

Figure 5

Game flowchart

In this thematic game, the idea of visual design can divide into several parts, namely the purposes of visual character design, background visual design concepts, and visual design concepts of game supporters. The idea of visual design can describe in the sections below: Visual character concept. This thematic game has two types of character designs. The main character designs are the character of boys and girls. The supporting character design is the character of the teacher and the NPC. Character design references based on concepts 1) elementary school children both male and female wear school uniforms and wear daily clothes; 2) the idea of the teacher here uses the purposes of the teacher using a national teacher uniform. 

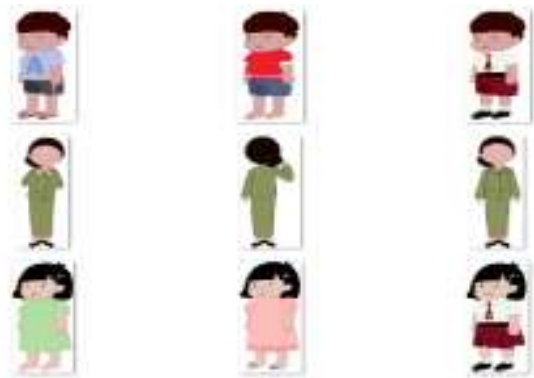

Figure 6

Main character

Visual background game concept, for the visible background of this game, can be divided into two parts, namely the main background design and design background of the minigame. Main Background visual design, In the @KAR educational game, there are 3 background designs, where the background design based on the element of review in this @KAR educational game. Main background design: school, Background design: the theme of knowledge using the school concept. School as a visualization concept because school is a place to get an education. Selection of school locations that have the characteristics and style of the city of Malang. Based on data studies, the school that has become a reference and has an extraordinary history is a monument area school in the city of Malang.

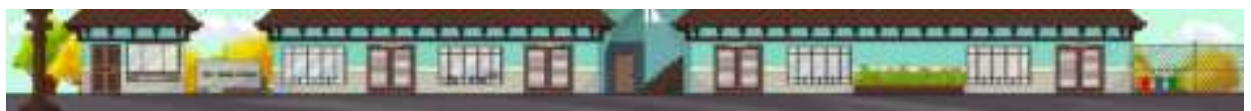

Figure 7

School asset background

\section{Data Analysis}

This data analysis was taken based on the initial and final tests through questions in the form of 5 answers, namely, very less, less, enough, good, and very good. Based on the results of data analysis in the final evaluation, it is obtaining the control class and experimental class data.

Table 9

Experimental control paired samples statistics

\begin{tabular}{llllll}
\hline & & Mean & N & Std. Deviation & Std. Error Mean \\
\hline Pair 1 & PRE & 11.07 & 83 & 1.528 & 0.168 \\
\cline { 2 - 6 } & POST & 17.99 & 83 & 1.750 & 0.192 \\
\hline
\end{tabular}

Table 9 above shows a summary of the results of descriptive statistics from the two samples (Pre and Post) in the experimental class, for the Pre value obtained an average (Mean) of 11.07. 
Table 10

Experimental class paired samples correlations

\begin{tabular}{lllll}
\hline & $\mathrm{N}$ & Correlation & Sig. \\
\hline Pair 1 & PRE \& POST & 83 & -0.146 & 0.189 \\
\hline
\end{tabular}

Table 10 above shows the correlation test results or the relationship between the Pre and Post variables in the experimental class.

Table 11

Paired samples test

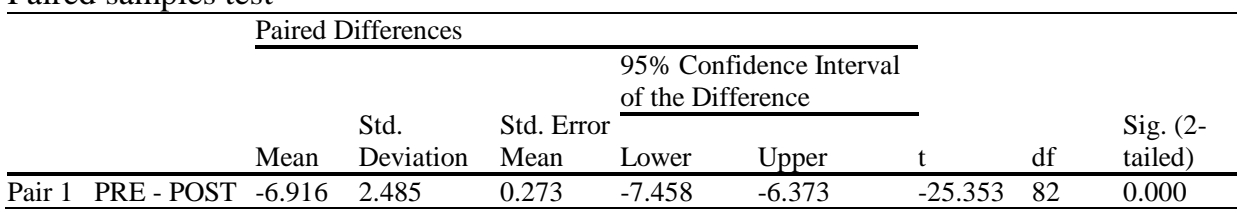

The table 11 above is the main table that shows the results of the tests (Paired Sample tTest). This table can see from the significance value (2-tailed) in the table.

Table 12

Class control paired samples statistics

\begin{tabular}{llllll}
\hline & & Mean & $\mathrm{N}$ & Std. Deviation & Std. Error Mean \\
\hline \multirow{2}{*}{ Pair 1 } & PRE & 10.81 & 86 & 1.712 & 0.185 \\
\cline { 2 - 6 } & POST & 12.59 & 86 & 1.529 & 0.165 \\
\hline
\end{tabular}

Table 12 above shows a summary of the results of descriptive statistics from the two samples (Pre and Post) in the control class. For the value of Pre obtained an average (Mean) of 10.81 .

Table 13

Class Control Paired Samples Correlations

\begin{tabular}{lllll}
\hline & & $\mathrm{N}$ & Correlation & Sig. \\
\hline Pair 1 & PRE \& POST & 86 & -0.002 & 0.983 \\
\hline
\end{tabular}

Table 13 above shows the correlation test results or the relationship between the Pre and Post variables in the control class.

Table 14

Class control paired samples test

\begin{tabular}{|c|c|c|c|c|c|c|c|c|}
\hline \multicolumn{6}{|c|}{ Paired Differences } & \multirow[b]{3}{*}{$\mathrm{t}$} & \multirow[b]{3}{*}{$\mathrm{df}$} & \multirow{3}{*}{$\begin{array}{l}\text { Sig. (2- } \\
\text { tailed) }\end{array}$} \\
\hline & \multirow[b]{2}{*}{ Mean } & \multirow{2}{*}{$\begin{array}{l}\text { Std. } \\
\text { Deviatio } \\
\text { n }\end{array}$} & \multirow{2}{*}{$\begin{array}{l}\text { Std. } \\
\text { Error } \\
\text { Mean }\end{array}$} & \multicolumn{2}{|c|}{$\begin{array}{l}\text { 95\% Confidence Interval of } \\
\text { the Difference }\end{array}$} & & & \\
\hline & & & & Lower & Upper & & & \\
\hline Pair 1 PRE - POST & -1.779 & 2.298 & .248 & -2.272 & -1.286 & -7.180 & 85 & 0.000 \\
\hline
\end{tabular}

Table 14 above is the main table that shows the results of the tests (Paired Sample tTest). We can see from the significance value (2-tailed) in the table. 


\section{DISCUSSION}

Basic analysis assessment for each minigame that carries the LAN, PAN, and SAN code values. Where each value code is in charge of 5 minigame values based on the type of theme. For example, a LAN value code is a combination of values from environmental sub-themes. The sum of 5 minigames in the environment theme. The minigame is Arranging Mading, Arranging Puzzles, Clearing Houses, Feeding Animals, and Getting to Know Animals. The Minigame will oversee the LAN1, LAN2, LAN3, LAN4, and LAN5 value codes. The value will add up, processed, and entered into LAN variables as environmental theme values. The same thing will apply to the amount of the school theme and the theme of association. In the game analysis interface, there is information related to the assessment per sub-theme and evaluation of each minigame.

Based on table 9, summary results of descriptive statistics from the two samples (Pre and Post) in the experimental class, for the Pre value obtained an average (Mean) of 11.07. As for the Post, the value gained an average (Mean) of 17.99. The number of respondents used as research samples was 83 students. The standard deviation (Std. Deviation) in Pre is 1.528 and in Post is 1.750 . For the Standard error mean value (Std. Error Mean) in Pre is 0.168 and in Post 0.192. Because the average cost in Pre (11.07) $<$ Post (17.99) means descriptive, there are an average difference and an increase between the Pre and Post values in the experimental class.

Based on table 10, shows the correlation test results or the relationship between the Pre and Post variables in the experimental class. Based on the table above, it's known that the correlation coefficient (Correlation) of -0.146 with a significance value (Sig.) Of 0.189 . Because of the amount of Sig, 0.189>0.05, it can be said that there is no relationship between the Pre and Post variables in the experimental class.

Based on table 11 shows the results of the tests (Paired Sample t-Test). This table can see from the significance value (2-tailed) in the table. Sig value (2-tailed) in the table above is 0,000 , where the number is less than $0.05(0,000<0.05)$, meaning that there are significant differences in the Pre and Post values in the experimental class. Based on descriptive statistics, the Post value is higher than the Pre value. This table shows that the students' insights about the thematic material experienced a significant increase. The data above, there is also a Mean Paired Differences value of $-6,916$. This value is the difference between the average Pre value and the average Post value.

Based on table 12 above shows a summary of the results of descriptive statistics from the two samples (Pre and Post) in the control class. For the value of Pre obtained an average (Mean) of 10.81. As for the Post, the value gained an average (Mean) of 12.59. The number of respondents used as research samples was 86 students. The standard deviation (Std. Deviation) in Pre is 1,712 and in Post is 1.529. For the Standard error mean value (Std. Error Mean) in Pre is 0.185 and in Post 0.165 . Because the average cost in Pre (10.81) <Post (12.59) means descriptive, there are an average difference and an increase between the Pre and Post values in the control class.

Based on table 13, shows the correlation test results or the relationship between the Pre and Post variables in the control class. Based on the table above, it's known that the 
correlation coefficient (Correlation) of -0.002 with a significance value (Sig.) Of 0.983 . Because of the amount of Sig, 0.983>0.05, it can say that there is no relationship between the Pre and Post variables in the control class.

Based on table 14, the main table that shows the results of the tests (Paired Sample tTest). We can see from the significance value (2-tailed) in the table. Sig value (2-tailed) in the table above is 0,000 where the number is less than $0.05(0,000<0.05)$, meaning that there are significant differences in the Pre and Post values in the control class. Based on descriptive statistics, the Post value is higher than the Pre value. This table shows that the student's insights about the thematic material experienced a significant increase. The data above, there is also a Mean Paired Differences value of -1.7779 . This value is the difference between the average Pre value and the average Post value.

\section{Research Question no 1}

Descriptive statistics show that the control class and the experimental class have increased insight into the thematic material. The students 'initial insight data (pre) in the control group was $\mathrm{M}=10.81$ ( $\mathrm{SD}=1.712)$, and in the experimental group was $\mathrm{M}=$ 11.07 ( $\mathrm{SD}=1.528)$, indicating that there were small differences in students' initial abilities. Data on students' insights after being given the media material thematic (post) in the experimental class showed data in the control class of $\mathrm{M}=12.59(\mathrm{SD}=1.529)$ and the experiment class of $\mathrm{M}=17.99(\mathrm{SD}=1,750)$ indicating that there were significant differences in student's final ability. The experimental group $(M=6.916)$ experienced a higher increase in the level of student insights regarding the thematic material compared to the control class $(M=1.779)$. Thus, there are differences between types treated using thematic material media and without using thematic material media in terms of increasing students' insight about thematic material.

The results of the Paired Sample t-Test analysis for the control class showed that the average insight of students about the thematic material was $-1,779(\mathrm{SD}=2,298)$ with a value of $\mathrm{t}=-7,180$, and $\mathrm{p}(0,000)<0.05$. That's means that students' insights about the thematic material in the control group increased significantly. Meanwhile, the results of the Paired Sample t-Test analysis for the experimental class showed that the average insight of the students regarding the thematic material was $-6,916(\mathrm{SD}=2,485)$ with $\mathrm{t}$ value $=-25,353$ and $\mathrm{p}(0,000)<0.05$. That's means that students' insights about the game thematic material in the experimental group also increased significantly. 


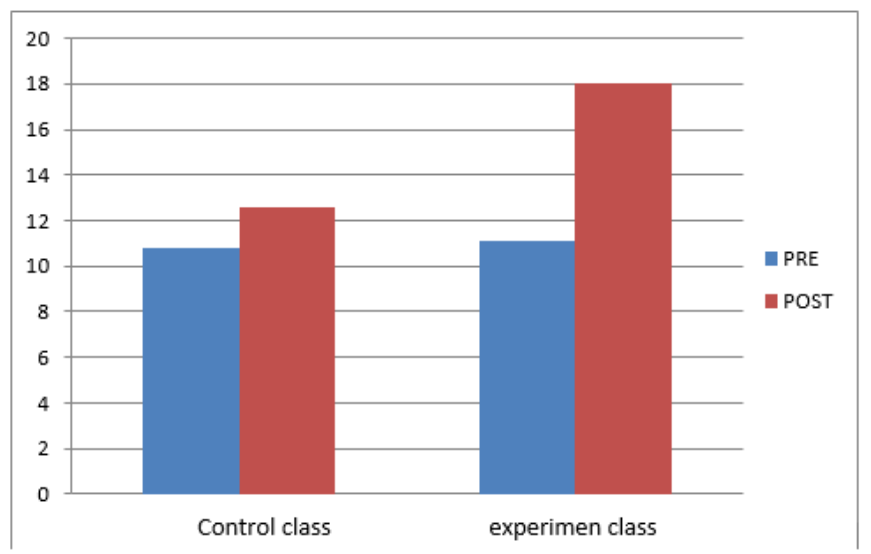

Figure 17

Analysis of interface design

\section{Research Question no 2}

ANCOVA test results showed that there were significant differences between the control class and the experimental class in influencing students' level of knowledge / insight about thematic material with a significance value of $0,000<0.05$.

Table 12

Tests of between-subjects effects

\begin{tabular}{lllllll}
\hline Dependent Variable: & POST & & & & & \\
Source & $\begin{array}{l}\text { Type III Sum } \\
\text { of Squares }\end{array}$ & df & Mean Square & F & Sig. & $\begin{array}{l}\text { Partial Eta } \\
\text { Squared }\end{array}$ \\
\hline Corrected Model & $1231.698^{\mathrm{a}}$ & 2 & 615.849 & 228.523 & 0.000 & 0.734 \\
\hline Intercept & 932.915 & 1 & 932.915 & 346.177 & 0.000 & 0.676 \\
\hline PRE & 2.388 & 1 & 2.388 & 0.886 & 0.348 & 0.005 \\
\hline KELAS & 1230.123 & 1 & 1230.123 & 456.461 & 0.000 & 0.733 \\
\hline Error & 447.355 & 166 & 2.695 & & & \\
\hline Total & 40944.000 & 169 & & & & \\
\hline Corrected Total & 1679.053 & 168 & & & & \\
\hline
\end{tabular}

R Squared $=0.734$ (Adjusted R Squared $=.730$ )

\section{Research Question no 3}

on the results of the study found a change in learning models conducted by the experimental class teacher. In the control class, the teacher still uses the traditional learning model based on the existing book material. In the implementation of the experimental class, the teacher makes a learning model based on the @ kar game media

\section{CONCLUSION}

Thematic learning for elementary school students based on games that run on Android is a strategy to facilitate thematic learning themes. Through Android-based thematic 
games, students can learn thematic anywhere, anytime, and with anyone. Besides, the development of learning is not only limited to this thematic learning game. Learning content related to thematic themes started from this learning game as thematic message delivery, then it will still be conveyed through the teacher. So the role of the teacher is even functioned in the delivery of thematic messages. Based on the purpose of this study, the results of the review and descriptive statistics show that the control class and the experimental class have increased environmental insight, the level of knowledge about thematic material, and found changes in learning models, student learning activities, and supporting assessments.

\section{ACKNOWLEDGMENT}

We are grateful to the school, teachers, and students who participated in this research. This research support by the Institute of Research and Community Services of the State University of Malang (Universitas Negeri Malang).

\section{REFERENCES}

Astutik, P. P. (2016). Integrasi Penguatan Pendidikan Karakter (PPK) Dan Higer Order Thinking Skills (HOTS) dalam Pembelajaran Tematik SD. Fakultas Ilmu Pendidikan Universitas Negeri Malang.

Bae, E. (2002). The Effects of Trainee Characteristics on Training Effectiveness in Improving Organizational Performance. Performance Improvement Quarterly, 15(2), 47-60. https://doi.org/10.1111/j.1937-8327.2002.tb00249.x

Besgen, A., Nilgun, K., \& Sara, F. (2015). Teaching/Learning Strategies Through Art: Art and Basic Design Education. 4th World Conference on Educational Technology Researches (WCETR-2014), 182, 428-432. https://doi.org/10.1016/j.sbspro.2015.04.813

Borg, W. R., \& Gall, J. P. (2003). Educational Research: An Introduction, 6th Edition. Diambil dari https://www.pearson.com/us/higher-education/product/Gall-EducationalResearch-An-Introduction-7th-Edition/9780321081896.html

Chien-Hung Lai, Yu-Chang Lin, Bin-Shyan Jong, \& Yen-Teh Hsia. (2014). Adding Social Elements to Game-Based Learning. International Journal of Emerging Technologies in Learning, 9(3), 12-15. http://dx.doi.org/10.3991/ijet.v9i3.3294

El-Abd, M. (2017). A Review of Embedded Systems Education in the Arduino Age: Lessons Learned and Future Directions. International Journal of Engineering Pedagogy, 7(2), 79-93. https://doi.org/10.3991/ijep.v7i2.6845

Fill Me App: An Interactive Mobile Game Application for Children with Autism. (2016). International Journal of Interactive Mobile Technologies, 10(3), 59-63. http://dx.doi.org/10.3991/ijim.v10i3.5553

Fozdar, B. I. (2015). Open and Distance Learning (ODL): A Strategy of Development through its Potential Role in Improving Science \& Technology Knowledge. 
International Journal of Emerging Technologies in Learning, 10(2), 9-16. http://dx.doi.org/10.3991/ijet.v10i2.4176

Hays, R. T. (2005). The Effectiveness of Instructional Games: A Literature Review and Discussion. TECHNICAL REPORT, 004.

Hosseini, H., Hartt, M., \& Mostafapour, M. (2019). Learning IS Child's Play: GameBased Learning in Computer Science Education. Journal ACM Transactions on Computing Education, 19(3). https://doi.org/10.1145/3282844

Kokkalia, G. K., \& Drigas, A. S. (2015). Tools and E-tools for Memory and Attention Problems in Pre-school Education. International Journal of Recent Contributions from Engineering, Science \& IT, 3(3), 13-19. http://dx.doi.org/10.3991/ijes.v3i3.4729

Kokkalia, G. K., \& Drigas, A. S. (2016). Mobile Learning for Special Preschool Education. International Journal of Interactive Mobile Technologies, 10(1), 60-67. http://dx.doi.org/10.3991/ijim.v10i1.5288

Kristianti, N., Purnawati, N., \& Suyoto. (2018). Virtual Education with Puzzle Games for Early Childhood: A Study of Indonesia. International Journal of Engineering Pedagogy, 8(2), 14-22. https://doi.org/10.3991/ijep.v8i2.7943

Manuaba, I. B. K. (2017). Text-Based Games for Improving Reading Behaviour in Indonesia. International Conference on Computer Science and Computational Intelligence 2017, 2nd, 14-26. https://doi.org/10.1016/j.procs.2017.10.041

Nakpong, N., \& Chanchalor, S. (2019). Interactive Multimedia Games to Enhance the Emotional Intelligence of Deaf and Hard of Hearing Adolescents. International Journal of Instruction, 12(2), 305-320. https://doi.org/10.29333/iji.2019.12220a

Papoutsi, C., \& Drigas, A. S. (2016). Games for Empathy for Sensitive Social Groups. International Journal of Recent Contributions from Engineering, Science \& IT (iJES), 4(3), 39-43. https://doi.org/10.3991/ijes.v4i3.5923

Rabin, S. (2010). Introduction to Game Development (Vol. 2). Charles River Media.

Sabani, A. C., Manuaba, I. B. K., \& Adi, E. (t.t.). Gamification: Blood Donor Apps for iOS Devices. Journal of Game, Game Art and Gamification, 01(01), 14-26.

Sasmito, L. F., \& Mustadi, A. (2015). Pengembangan lembar kerja peserta didik tematik-integratif berbasis pendidikan karakter pada peserta didik sekolah dasar. Jurnal Pendidikan Karakter, (1).

Shuqin, S. (2012). Cultural and Creative Industries and Art Education. 2012 International Conference on Medical Physics and Biomedical Engineering (ICMPBE2012), 33, 1652-1656. https://doi.org/10.1016/j.phpro.2012.05.266

Syahidi, A. A., Supianto, A. A., \& Tolle, H. (2019). Design and Implementation of Bekantan Educational Game (BEG) as a Banjar Language Learning Media. International Journal of Interactive Mobile Technologies (iJIM), 13(03), 108-129. https://doi.org/10.3991/ijim.v13i03.9257 
Sofiana, N., \& Mubarok, H. (2020). The Impact of Englishgame-Based Mobile Application on Students' Reading Achievement and Learning Motivation. International Journal of Instruction, 13(3), 247-258. https://doi.org/10.29333/iji.2020.13317a

Sugiyono. (2008). Metode penelitian pendidikan:(pendekatan kuantitatif, kualitatif dan R \& D). Alfabeta

Wallace, L., \& Sheetz, S. D. (2014). The adoption of software measures: A technology acceptance model (TAM) perspective, Information \& Management, 51(2), 249-259. https://doi.org/10.1016/j.im.2013.12.003

Willet, B. S., Sukanya, M., Boltz, L., Greenhalgh, S., \& Koehler, M. (t.t.). Back to the Gaming Board: Understanding Games and Education through Board Game Reviews. Society for Information Technology \& Teacher Education International Conference, Mar 26, 2018 in Washington, D.C., United States, Association for the Advancement of Computing in Education (AACE). 